Kong. Res. J. 4(1) : 22-24, 2017

ISSN 2349-2694

Kongunadu Arts and Science College, Coimbatore.

\title{
AN ECOFEMINIST READING OF ANITA DESAI'S FIRE ON THE MOUNTAIN
}

\author{
Nila, $\mathbf{N}$. \\ Department of English, Mercy College, Palakkad. \\ E.mail: doctornila@gmail.com
}

\begin{abstract}
Ecofeminism is a term that links feminism with ecology. This paper tries to outline the fact that the capitalistic society has led to a conflict between nature and culture. This also makes it clear that the exploitation of nature and the oppression of women are closely linked with notions of class, caste, race, colonialism and social rules. Anita Desai, in Fire on the Mountain emphasis ecoconsciousness by depicting a serene landscape. She also takes the reader through a maze of human actions, diverse nature of the mountain, the ecological natural processes in the mountain milieu, excessive population disturbing the peace ,man-made dangers exploiting nature; and therefore aims at showing an integral relationship between man and nature. The novel certainly recalls the fact that mother earth suffers just like women living on her, exploited, discriminated, humiliated, raped, disowned, discarded and let to die.
\end{abstract}

Keywords: Ecofeminism, Anita Desai, Fire on the Mountain.

Ecofeminism is a term that links feminism with ecology. The term is believed to have been coined by the French writer Francoise d'Eaubonne in her book Le Féminisme ou la Mort (1974). From arguments that there are particular and significant connections between women and nature, ecofeminism interprets their repression and exploitation in terms of the repression and exploitation of the environment. Ecofeminists believe that these connections are illustrated through traditionally "feminine" values such as reciprocity, nurturing and cooperation, which are present both among women and in nature. Women and nature are also united through their shared history of oppression by a patriarchal society. This paper tries to outline the fact that the capitalistic society has led to a conflict between nature and culture. This also makes it clear that the exploitation of nature and the oppression of women are closely linked with notions of class, caste, race, colonialism and social rules. Anita Desai, in Fire on the Mountain emphasis ecoconsciousness by depicting a serene landscape. She also takes the reader through a maze of human actions, diverse nature of the mountain, the ecological natural processes in the mountain milieu, excessive population disturbing the peace ,man-made dangers exploiting nature; and therefore aims at showing an integral relationship between man and nature. The novel certainly recalls the fact that mother earth suffers just like women living on her, exploited, discriminated, humiliated, raped, disowned, discarded and let to die.
A lot of women have led environmental causes and movements such as Arundhati Roy, Medha Patkar, Mahasweta Devi, and C.K Janu. MedhaPatkar leads the Narmada BachaoAndolan, a social movement consisting of tribal people, farmers, environmentalists and human rights activists against the SardarSarovar Dam being built across the Narmada river in Gujarat,India. Mahasweta Devi, is an activist as well as a well-known feminist writer. She has dedicated much of her activism and literature to the cause of betterment of the tribal people and their environment in India. Arundhati Roy, who won the Booker Prize for her The God of Small Things, writes for various causes such as the Narmada BachaoAndolan, nuclear testing in India, and the support of the separatists' demand for freedom in Kashmir. Then comes C.K Janu, as recent as the year 2003 onwards, an adivasi woman occupying the Muthanga forests in North Kerala. This was to protest the breached agreement between the adivasis and the state govenrment to provide 500 acres of land to each adivasi family.

In the wake of activists and writers of this kind we find Anita desai portraying the darker shades of nature and the simultaneous conjunction of the darker aspects of the women concerned in her novel Fire on the Mountain.The protagonist is Nanda Kaul who wants to enjoy solace on the lap of nature in Kasauli and consider it a peaceful retirement resort after having a life full of troubles and the labour of daily routine. She wants to do away with the disturbing mundanity. She gets a call from her daughter to be ready to accept her great grand 
daughter Raka and keep her at Carignano for a while. She, deep inside her heart, did not want the company of Raka who wanted to come to Kasauli because everyone told her that in Kasauli, nature worked wonders. The way the characters are shown bring alive certain situations in their lives and are similar to images as nature has its relationship towards living organisms. The novel depicts multidimensional forms of living. These images have been employed to examine human relationships and their significance. The unconventional choice, of retiring from the family's responsibilities, made by Nanda may not be highly appreciated but she is forced to come to a compromise. She is quite sure that she has completed her duty in life by seeing her family and kin well cared for by herself through out her life and takes a decision to "be left to the pines and cicadas alone she hoped she would not stop" (3). She is pleased and satisfied with the place and landscape around her. "Everything she wanted was here, at Carignano, in Kasauli. Here, on the ridge of the mountain, in this quiet house" (3). Due to the passage of time she enters in the world of old age. She embodies a tree out there to bear the unpredictable seasonal difference of life. "Whatever else came, or happened here, would be an unwelcome intrusion and distraction"(3).

She is grey, tall and thin and she fancies "she could merge with the pine trees and could be mistaken for one. To be a tree, no more and no less, was all she was prepared to undertake"(4). Nanda is attracted to Carignano for 'its barrenness that equalizes her. The lonely house is symbolic of the solitary life of Nanda.

Anita Desai has correctly brought out the sight of an eagle or a bright hope served to delight her otherwise solitary existence. Ecocriticism evolves not only through the ecological concerns but through description of landscape and imagination of nature and climatic intervention. It draws a meaningful link between animate and inanimate relationships.

Desai's novel is a blend of nature and characters and her novel is rich in exotism that they represent their own individuality. Man has turned into a machine now because life has started to depend more on technology than on anything else. Human beings are ussing natural resources to satisfy their own needs and desires. In Carignano once upon a time garden house was the most beautiful garden in Kasauli, now it has been used as an army camp. It clearly depicts the insensitivity of man towards nature and patriarchal attitude in destroying the natural phenomena. Literally man has exploited nature like an object for his own pleasure. Here Anita Desai wants us to draw the attention of the degradation of the ecological balance. She depicts the aesthetic experiences drawn from the nature and that makes the human beings live in peace and harmony regardless of our pathetic life in the world. In fact Anita Desai has incorporated environmental attitudes in her novels, which speak about animate and inanimate things that surround the entire natural ecosystem.

When Raka slipped out of the window to have a better look at the landscape on her first expedition to study the mountains she saw:

Shoals of rusted tins,bundles of stained newspaper,peel,rags and bones,all snuggling in grooves, hollows, cracks, and sometimes spilling. Pine trees with charred trunks and contorted branches, stiking melodramatic attitudes as on stage."(46)

As soon as Raka looks at the landscape, these are scenes that evolve in front of her and she wondered why Great grandma had never seen the factory or the ravaging of the near by ravine because of the waste dumped by the factory workers or the gutter that carried the dirty water to the rivulets nearby. She feels her father and grandmother had extolled the beauties of the Himalayan Hill Station to her but never said anything about the factories.. Anita Desai remarks: "To her, it seemed to dominate the landscape-a square dragon, boxed,bricked and stoked"(46).

She even asked Ram Lal the caretaker why the factory emitted so much smoke. He explains that they made serum for the whole country and remarked "See those chutes? They empty the bones and ashes of dead animals down into the ravine. It's bad place.Don't go there."(47).

Even the air smeltof cinders, serum boiling,chloroform and spirit,dog's brains,boiled vats,of guinea pigs' guts and so on. How can the Himalayan beauty which is an unsustainable view for an English artist, where hills melted into sky, sky into snow, snows into air be considered retain her serenity with draconian invasions such as this?

Another blow to nature in those divine mountains was the burnt black shell of a house. It was burnt down in a summer fire when there was no water to fight it out. Then comes the once upon a time beautiful Garden House of Kasauli turned into an army billet The area has an atomic reactor and lot 
of barbed wire around. Changing the quiet, complacent and peaceful area into a war zone.

The novel goes on to bring Ila Das to visit Nanda. She is the Welfare officer of the Government and tries to educate people to take a child infected with tetanus to the clinic straight away. But superstitious believes take more time before he could be taken to a doctor and the boy dies. She also tries to stop a child marriage and ends up having enemies she herself is not ware of. She tries to tackle the father Preet Singh but could not convince him.

The night she returns from Carignano she gets late after buying things, even the footpath already was lost in the evening shadow of the mountains. She stumbled over the pebbles and rocks.. She is accosted by a man who held her throat hard. He tore at her clothes, rapped her,pinned her down and strangulates her. She dies. This brings out the punishment given to her by a dominating male figure of the locality for intruding into his affairs. He has been a beast in his reaction not understanding that Ila Das had after all tried to save his own child from misfortune. He had no foresight, no forethought nor any understanding of what the future had in stake for his daughter, but his patriarchal ego would let his inner eye open up.

The novel ends by depicting Raka taking a match box from the kitchen without the knowledge of Ram Lal and setting fire to the dry grass in the near by forest. The flames spread down the ravine as she runs home and tell Nanda "Look Nani, I have set the forest on fire. Look, Nani-Look-the Forest is on fire" (159). Perhaps she felt the clumps of trees, the ravine, the hill tops and the rocks never had anything positive now to offer as where ever she turned there was only dryness, stench and destruction of nature.
So is the plight of Nature. Man is tearing at nature, the green mountains look plush and miraculous, but a closer look will reveal the sickening silence in the face of the ravines polluted with remains of dead animals and strains of chemicals being sent out of the factories. The hilltops seem to radiate with willows and flowering plants but they had frizzled grass and blazed rocks, bleached and blackened by fire. Man has driven the divine out of the hills, torn at her, sent out the sweet fragrance and filled her with filth, made her dry, dusty, dull and drained of all the goodness; There was no song to sing of her, except that she has been cheated. In the name of enjoying her company she has been devastatingly exploited, to only be expended and then to be put to an end. Ecology and Ecofeminism go hand in hand. Just as man destroys the essence of womanhood by ill treating and abusing her, he also gives devastating blows to nature by using her too much without thinking of providence. Leaving us wondering how mother earth suffers just like women living on her, exploited, discriminated, humiliated, raped, disowned, discarded and let to die. If there is no importance given to feminine values such as reciprocity, nurturing and cooperation, which are present both among women and in nature the globe will soon lose its charm and to what end... is a million dollar question.

\section{REFERENCES}

Desai, Anita. 2008. Fire on the Mountain. United Kingdom,Random House India.

Tharu, Susie and K. Lalita 2000. Women Writing in India 600 B.C. to the Present. New Delhi. Oxford University Press.

Walters, Margaret 2007. Feminism A Very Short Introduction.New Delhi. Oxford University Press. 